\title{
Application Of Value Clarivication Technique Models To Improve Civic Disposition Of Elementary School Students
}

\author{
Nurfaizah.AP \\ \{a.p_nurfaizah@yahoo.com\} \\ ${ }^{1}$ Primary Teacher Education, Faculty of Education, Universitas Negeri Makassar, \\ Makassar, Indonesia
}

\begin{abstract}
This study aims to describe the improvement in Civic Disposition of Primary School Students through the application of the Value Clarivication Technique Model. This research is a classroom action research using descriptive qualitative methods. Data were collected through observation, documentation and daily notes. The data collected were analyzed using descriptive statistics. Increased civic disposition can be seen from the results of observations of the first cycle which shows as many as 6 indicators out of all 8 indicators that met the success criteria. In cycle II, all indicators measured increased and $>60 \%$ or in accordance with expected indicators of research success. It can be concluded that the application of the Value Clarivication Technique model can improve students' civic Disposition.
\end{abstract}

Keywords: Civic Disposition, Value Clarification Technique Model

\section{Introduction}

Citizenship Education has a mission in forming good and smart citizens. Good and intelligent / educated citizens are characterized by three important competencies, namely civic knowledge, civic disposition and civic skills. To be a good and smart citizen, the three competencies must be balanced and hand in hand. Students as young citizens need to be prepared early to be able to play a role in the life of the nation. Civic disposition is closely related to the development of students' attitudes and character. Therefore learning at schools actually plays an important role in improving the character of students as young citizens. Civic disposition or character of citizenship should need more attention even though in reality it is often overlooked.

At present Indonesia is experiencing a decharacterization marked by national issues. Character problems are not only faced by one school or university, but also by all Indonesian citizens. Various mass media, both print and electronic media, aired news of criminal cases of political elite, rape and murder cases, violance and many others related to social issues. This indicates that the character problems in Indonesia are already acute to be immediately overcome. Samani and Hariyanto (2013: 2) stated that character education in Indonesia is very urgent to be carried out optimally, the increasing widespread of juvenile delinquency forms such as student-student brawls, violence including bullying, drugs and the most surprising is 
the effort to build honesty between students through the honesty canteen failed due to bankruptcy. These cases indicate the low civic Disposition of citizens.

The problem of low civic disposition of citizens was also observed at SD Inpres 3/77 Manurungge, Bone Regency. Based on the results of observations, some problems were found, especially in class V. In fact, some students' attitudes less reflect the good characters, namely: 1) religious issues such as students who are less obedient in carrying out religious education, play and not being serious when praying, and lack of respect for the environment such as littering, 2) nationalism issues such as picking friends, not respecting diversity and lacking discipline when entering class, 3) independence issues such as lack of responsibility when burdened with tasks in the learning process, and lack of confidence, 4) mutual cooperation problems such as lack of care about the problems being faced by friends, lack of cooperation and work together to solve tasks / problems together, 5) integrity issues such as the attitude and language of students who are not polite when communicating with friends or teachers.

Based on information from the fifth grade teacher of SD Inpres 3/77 Manurunge about the learning process, that so far in general the teacher only applies a learning model that emphasizes more on students' cognitive abilities. This reflects that the expected orientation of learning outcomes is merely centered on the cognitive domain which means emphasizing only the dimensions of civic knowledge. While civic skills and civic dispositions are lack of attention. The above conditions need to be anticipated, because if the learning conditions are not able to touch all aspects of student learning, it will certainly have a negative impact on the development of student character as citizens. To anticipate this, the teacher is required to be skilled in choosing models and methods that are able to touch these three aspects of learning, replacing learning models that have so far only knowledge oriented into learning models that are attitude oriented.

Value Clarification Tehnique (VCT) is one of the learning models that can meet the goals of attitude formation. Value clarification technique or often abbreviated as VCT can be interpreted as a teaching technique to assist students in finding and determining a value that is considered good in dealing with a problem through the process of analyzing existing values and embedded in students. This model was chosen by researchers because it was felt to be suitable for improving student character.

For this reason, research on the VCT learning model to improve student civic disposition becomes very important to do in order to design the right solution for the character problems of Indonesian young generation, especially preparing citizens' competencies.

\section{LITERATURE REVIEW}

1. Value Clarification Technique Model

Value Clarification Tecnique is a teaching technique to help students accept and determine the value system that is considered good in dealing with a problem through the process of analyzing existing values embedded in students (Suyadi, 2018: 200). Hall (Adisusilo: 2017) states that the value clarification technique emphasizes efforts to help a person / student in assessing their own feelings and actions, increase their awareness of their own values and encourage them to form their own value systems and practice them in daily life. According to Taniredja, et al. (2017: 88) the purpose of using VCT in Citizenship Education learning is: 1) to know and to measure the level of student awareness about a value, so that it can be used as a basis to determine the target value to be achieved, 2) to instill student awareness about the values possessed both the level and 
nature of positive and negative to further instilled in the direction of improvement and achievement of target values, 3) to instill certain values to students through rational ways and to be accepted by students, so that ultimately these values will belong to students as a process of moral awareness rather than a moral obligation, 4) to train students in accepting and assessing their own value and the value position of others, accepting and making decisions on an issue related to their relationships and daily life.

There are five principles of Value Clarification Technique according to Taniredja, et al. (2017) namely as follows: 1) Value increment and attitude change are influenced by many factors including self potential; emotional, intellectual, and environmental sensitivity; community value norms, education systems, family environment and play environment. 2) Attitudes and attitude changes are influenced by stimuli received by students and the strength of values that have been embedded or possessed in students, 3) 3) Values, morals, and norms are influenced by developmental factors, so the teacher must consider the level of moral development of each student. 4) Changing attitudes and values requires skills to clarify values / attitudes rationally, so that students appear in selfawareness not because of a sense of duty to behave in a certain way or to do certain things. 5) Changing values requires openness, therefore Citizenship Education learning through VCT requires openness between teachers and students.

The operational steps in the teaching and learning process according to Aeni (2015: 197-198), namely: 1) Determination of stimulus. 2) Presentation of stimulus. 3) Determination of position / choice / opinion. 4) Test the reasons. 5) Conclusion and direction. 6) Follow up. The VCT model according to Djahiri (Taniredja, et al., 2017) has advantages because: 1) Being able to foster and instill values and morals in the realm of the internal side; 2) Being able to clarify / explore and express the contents of material delivered subsequently will make it easier for teachers to convey the values or moral messages; 3) Being able to clarify and assess the quality of students' moral values, see the values that exist in others and understand the moral values existing in real life; 4) Being able to invite, involve, foster, and develop students' self potential especially developing potential attitude; 5) Being able to provide a number of learning experiences from various lives; 6) Being able to prevent, negate intervene and integrate various moral values in the value and moral systems that exist in a person. 7) Being able to give a picture of deserved moral values, guide and motivate to live a decent and high moral.

Djahiri (Taniredja, 2017) argues that the weaknesses of VCT are: 1) If the teacher does not have the ability to involve students with openness, mutual understanding and full of warmth then students will bring up false or fake attitudes. Students will appear to be good and obedient students merely to please teachers or get good grades. 2) The lack and unstandardized value system owned and embedded by teachers, students and community can interfere with the achievement of the target of the standard value or ethical values. 3) Highly influenced by the ability of teachers to teach, especially the ability to ask high level questions in order to uncover and explore the existing values of students. 4) The teachers' creativity in using available media in the environment is required in actual and factual way to be contextual for students.

\section{Civic Disposition}

Civic disposition is one component of civic education. Civic disposition is translated as character, attitude, or character of citizenship. There are also those who call it civic value. Branson (Winarno, 2013: 177) states as follows "Civic disposition as the third basic component of civic education refers to public and private characters that are important for 
the maintenance and development of constitutional democracy". The main purpose of civic disposition is to foster the character of citizens, both personal character such as moral responsibility, self-discipline, and respect for the dignity and human dignity of each individual and public character such as caring as citizens, politeness, heeding the rules of man (rule of law), critical thinking, and a willingness to listen, negotiate and compromise. (Winarno, 2013). The development of Education initiated five main values of prioritized character in Penguatan Pendidikan Karakter (PPK) according to the Ministry of Education and Culture (2017), which are religious, nationalist, independent, mutuall cooperation and integrated. The five values can be described as follows:

1) Religious

The value of religious character reflects the faith in God Almighty and is manifested in the behavior of carrying out religious teachings and beliefs, respecting religious differences, upholding a tolerant attitude towards the implementation of others' religious worship and beliefs, living in harmony and peace with followers of other religions.

2) Nationalists

The value of nationalist character is a way of thinking, behaving, and acting that shows loyalty, care and high respect for the language, physical environment, social, cultural, economic, and political of the nation, placing the interests of the nation and state above self and group interests.

3) Independent

Independent character values are attitudes and behaviors that do not depend on others and use all energy, thoughts, and time to realize hopes, dreams and ideals. Independent sub-values include work ethic (hard work), resilience, fighting spirit, professionalism, creativity, courage, and lifelong learners.

4) Mutual Cooperation

The character value of mutual cooperation reflects the act of appreciating the spirit of cooperation and working hand in hand to solve common problems, to establish communication and friendship, to provide assistance / help to people in need. The mutual cooperation sub-values include respect, cooperation, inclusiveness, commitment to joint decisions, consensus agreement, help, solidarity, empathy, anti-discrimination, antiviolence, and voluntary attitudes.

5) Integrated

Integrated character values are values that underlie behavior based on efforts to be trusted in words, actions, and work, having commitment and loyalty to human values and morals (moral integrity). The character of integrity includes an attitude of responsibility as a citizen, actively involved in social life, through consistency in actions and statements based on truth. Sub-values of integrity include honesty, love for truth, loyalty, moral commitment, anti-corruption, justice, responsibility, example, and respect for the dignity of individuals (especially those with disabilities).

\section{RESEARCH METHOD}

This research is a classroom action research using a descriptive qualitative method. This type of research is classroom action research conducted in collaboration with teachers in fifth class at SD Inpres 3/77 Manurunge Tanete Riattang, Bone Regency in an effort to improve the quality of learning in the classroom through the application of VCT model to improve student civic disposition by designing, implementing, observing and reflecting. 
There are two focuses at the core of this study, namely the VCT Model. First, the ability of teachers to carry out learning in accordance with the steps of VCT model, especially in learning that is applied to fifth grade elementary school students and Civic Disposition which is focused on improving student civic disposition after carrying out learning with VCT model. Second is its manifestation in the form of an increase in the five main character values at school, namely religious, nationalist, independent, mutually cooperative, and integrited.

This research was conducted in class V SD Inpres 3/77 Manurunge which is in the even semester of the $2018 / 2019$ school year. The number of students is 12 people, consisting of 8 male students and 4 female students. The reason for choosing this subject is based on direct observation, that the fifth grade students of SD Inpres 3/77 Manurunge have a civic disposition problem whose solution is in accordance with the VCT learning model.

This study uses an action plan through classroom action research. According to Arikunto (2016) a research plan cycles consisting of planning, implementing, observing, and reflecting. The initial step in this research is to determine the plan that will be carried out covering activities to compile the lesson plan in accordance with the steps of the VCT learning model, to develop students worksheet and learning media such as providing learning videos, to prepare instruments in the form of observation sheets to observe teacher activity in the use of VCT learning models and observation sheets to observe students' civic disposition. In addition, the researcher also makes a rubric that will become the observer's reference in filling out the observation sheet.

The implementation phase is the implementation of lesson plan that has been arranged collaboratively between researchers, and teachers with the application of the VCT model in learning, namely: 1) determination of the stimulus used i.e video, 2) presentation of the stimulus is done by showing a video that contains a demonstration of behavior that reflects unity and behavior that does not reflect unity, as well as videos containing material about advertising, 3) determination of position / choice / opinion where students fill out the video observation worksheets distributed by the teacher. Students fill out based on the video that has been played, after that 4) testing the reasons was done by students presenting the answers in the worksheets that have been filled in, other students are asked to respond, 5) conclusion and direction, at this stage the teacher directs and concludes the problems discussed. The teacher directs students to find one value from the problem discussed and emphasizes to make the value a part of themselves, and 6) follow-up was in the form of remedial improvement activities or enrichment, answering questions, and extra activities / exercises / application of the trial test.

The Observation Phase is carried out by paying attention to the learning stages that occur at the beginning to the end of the learning activities. Monitoring the activeness, attitudes, and behavior of students when learning takes place based on the format that has been prepared. Observers pay attention to the extent of the success of teachers in learning through observing students' attitudes based on the format that has been prepared.

Based on the observations, a reflection is held to find out the weaknesses or deficiencies that occur in the first cycle and will be corrected in the next cycle. Reflection activities carried out based on the results of observation, the results of documentation, and observer input

Data collection techniques in this study were obtained from observations, documentation and daily records. Data analysis was performed after one learning cycle was carried out as a whole which was carried out with qualitative data analysis techniques. According to Miles and Huberman (Kunandar, 2008: 102) that "the analysis of the data consists of three components of activities that are interrelated to one another, namely data reduction, data display, and drawing conclusions. 
Indicators of success can be seen from two aspects, namely the success of the teacher in applying the VCT learning model and the success of students in the application of civic disposition seen from the achievement of indicators on religious, nationalist, independent, mutual cooperation, and integrity aspects. The success of the classroom action is determined by the increase in each cycle and shows a level of achievement> $65 \%$.

\section{RESEARCH RESULTS AND DISCUSSION}

\section{A. Research Results}

The study was conducted in 2 cycles with each cycle carried out in 2 meetings. In the first cycle, the process of implementing the VCT and civic disposition models was expected to be improved, but still in the moderate category. Increased civic disposition can be seen from the results of observations of the first cycle which shows that as many as 6 indicators out of all 8 indicators that have met the criteria for success. Whereas in the second cycle all indicators measured had increased and were in the good category of $>65 \%$ or in accordance with the expected indicators of research success.

\section{B. Discussion}

Increased student civic disposition in the first cycle in learning by using the VCT learning model is able to attract students' attention in learning, the video used makes it easy for students to understand the lesson. This is in accordance with the opinion of Djahiri (Taniredja, et. Al., 2017) that VCT is able to explore and express the contents of the message material delivered and will make it easier for teachers to convey meaning of moral and value messages. So students can make decisions about a value without feeling forced then become an example of good character that will be implemented in their daily lives. Improvement also occurs because the teacher has tried well not to force the choice of a value. This is in accordance with the opinion expressed by Harmin, et al (Adisusilo, 2017) the application of value clarification will be effective if the educator is to accept and not judge students' choices, avoiding the impression of giving advice.

In cycle 1 civic disposition students still did not reach the specified success indicator because the activities of students in the first cycle were not yet fully maximized, students were not accustomed to the applied VCT learning model. Student activities that have not been maximized in cycle I are testing the reasons. This is consistent with the opinion expressed by Harmin, et al (Adisusilo, 2017) the application of value clarification will be effective if the educator encourages students to answer, namely in the process of testing the reasons.

In cycle II the learning process by applying the VCT model can be considered good. The implementation of learning in the second cycle of civic disposition has reached the indicator of success due to an increase in students' civic disposition. Students who used to play when praying now look more serious, students who lack respect for friends who are different from themselves are now able to behave even better. Students who are reluctant to speak or express their opinions are now confident. The act of cleaning in group, polite speech and behavior begin to show. Based on the data described above and related to the theory in chapter II, namely affective learning using the VCT model according to Djahiri (Taniredja, et. Al, 2017) that the model is able to invite, involve, foster, and develop students' self potential especially developing potential attitudes, to provide a number of learning experiences from various lives, to give a picture of moral values that are worthy of acceptance and motivate to have decent lives and high moral. Besides that "the VCT learning model can help students find and 
determine a value that is considered good in dealing with a problem through the process of analyzing values" (Sanjaya, 2008).

\section{CONCLUSIONS AND SUGGESTIONS}

\section{A. Conclusion}

The learning process by applying the VCT Model can increase the civic disposition of fifth grade students of SD Inpres 3/77 Manurunge, Tenete Riattang District, Bone Regency. Through the five aspects of civic disposition indicators observed, namely religious, nationalist, independent, mutual cooperation, and integrity, it is shown that the percentage increased in civic disposition in the first cycle with a moderate category to a good category in the second cycle.

\section{B. Suggestion}

Teachers should use the VCT learning model as an alternative in learning because it is proven that it can improve students' civic Disposition.

\section{REFERENCE}

Adisusilo, Sutarjo. 2017. Pembelajaran Nilai-Karakter Konstruktivisme dan VCT sebagai Inovasi Pendekatan Pembelajaran Afektif. Jakarta: Rajawali Pers.

Aeni, Ani Nur. 2014. Pendidikan Karakter untuk Mahasiswa PGSD. Bandung: UPI Press

Aeni, Ani Nur. 2015. Ragam Model Pembelajaran di Sekolah Dasar (Edisi Kedua). Sumedang: UPI Sumedang Pers.

Arikunto, Suharsimi et al. 2016. Penelitian Tindakan Kelas. Jakarta: Bumi Aksara.

Branson, M. S. 1998. The Role of Civic Education: An Education Policy Task Force Position Paper With Policy Recommendations. Center for Civic Education. (Online) http://www.civiced.org/promote-rationale/position-paper-with-policyrecommendations (diakses 22 Maret 2019)

Haris, Fairiza. 2013. Penerapan Model Pembelajaran Value Clarification Technique (VCT) untuk Meningkatkan Kesadaran Nilai Menghargai Jasa Pahlawan pada Siswa Sekolah $\begin{array}{lllll}\text { Dasar. JPGSD } & \text { (Online), } & \text { Vol. } & 02 & \text { No. }\end{array}$ http://jurnalmahasiswa.unesa.ac.id/index.php/jurnal-penelitianpgsd/article/view/2981/1731 (diakses 02 Februari 2019).

Kementerian Pendidikan dan Kebudayaan dan Tim Komunikasi Pemerintah Kementerian Komunikasi dan Informatika. 2017. Penguatan Pendidikan Karakter Jadi Pintu Masuk Pembenahan Pendidikan Nasional. Jakarta: Kementerian Pendidikan dan Kebudayaan, Republik Indonesia.

Kunandar. 2008. Langkah Mudah Penelitian Tindakan Kelas Sebagai Pengembangan Profesi Guru. Yogyakarta: Raja Grafindo Persada.

Lexy, J. M. 2015. Metodologi Penelitian Kualitatif. Bandung: Remaja Rosdakarya.

Maisaro, A., Wiyono, B. B., \& Arifin, I. 2018. Manajement Program Penguatan Pendidikan Karakter di Sekolah Dasar. Jurnal Adminitrasi Dan Manajemen Pendidikan, Vol. 1 (3): 302-312.

Majid, Abdul. 2014. Pembelajaran Tematik Terpadu. Bandung: Remaja Rosdakarya

Mulya, Hendra. 2017. Penerapan Model Value Clarification Technique (VCT) untuk Meningkatkan Hasil Belajar Siswa Pada Pembelajaran PKn Kelas 5 Min Merduati 
Banda Aceh. Skripsi. Banda Aceh. Fakultas Tarbiyah dan Keguruan Universitas Islam Negeri Ar-Raniry.

Muslich, Masnur. 2015. Pendidikan Karakter Menjawab Tantangan Krisis Multidimensional. Jakarta: Bumi Aksara.

Pratiwi, Yessi Eka. 2017. Pengembangan Civic Disposition dengan Model Pembelajaran VCT Berbasis Couple Team. Jurnal Prosiding Konferensi Nasional Kewarganegaraan III. Vol. 3 (8): 255-262

Setiono, Kusdwiratri. 2008. Psikologi Perkembangan (Kajian Teori Piaget, Selman, Kohlberg, dan Aplikasi Riset). Bandung: Widya Padjajaran

Sugiyono. 2016. Metode Penelitian Kuantitatif Kualitatif dan R\&D. Bandung: Alfabeta.

Sukardi. 2015. Metode Penelitian Tindakan Kelas Implementasi dan Pengembangannya. Jakarta: Bumi Aksara

Suradi. 2018. Penerapan Model Pembelajaran Inside Outside Circle dalam Meningkatkan Hasil Belajar IPS Siswa Kelas V SDN 226 Pakkasalo Kecamatan Sibulue Kabupaten Bone. Skripsi. Makassar. Fakultas Imu Pendidikan. Universitas Negeri Makassar.

Suyadi. 2018. Strategi Pembelajaran Pendidikan Karakter. Bandung: Remaja Rosdakarya Taniredja, Tukiran, Evi Miftah Faridli, \& Sri Harmianto. 2017. Model-model Pembelajaran Inovatif dan Efektif. Bandung: Alfabeta.

Trianto. 2007. Pembelajaran Inovatif Berorientasi Konstruktivistik. Jakarta: Prestasi Pustaka Publisher

Undang-Undang Republik Indonesia Nomor 20 Tahun 2003. Undang-Undang Sistem Pendidikan Nasional. Jakarta: Departemen Pendidikan Nasional

Wardani, Naniek Sulistya. 2012. Asesmen Pembelajaran SD. Jakkarta: Widya Sari Pres Salatiga

Winarno. 2013. Pembelajaran Pendidikan Kewarganegaraan Isi, Strategi, dan Penilaian. Jakarta: Bumi Aksara. 
